\title{
DESIGN, MEASUREMENT AND ANALYSIS OF GYRO-AZIMUTHS INFLUENCE ON THE RESULTS OF ALIGNING THE UNDERGROUND CONTROL NETWORK
}

\author{
${ }^{1}$ AGH University of Science and Technology, szafarcz@agh.edu.pl \\ ${ }^{2}$ O/ZG Lubin KGHM Polska Miedź S.A, Jacek.Mlynarczyk@kghm.com \\ ${ }^{3}$ O/ZG Lubin KGHM Polska Miedź S.A., lukasz.Markiewicz@kghm.com \\ ${ }^{4}$ AGH University of Science and Technology, rgawal@wp.pl
}

Keywords: gyroscope, azimuth measurement, underground network alignment

\begin{abstract}
The article discusses the impact of additionally measured gyroazimuths on the accuracy of the underground network. It discusses such issues as: the way of gyroazimuth measurement, corrections introduced into the measured gyroazimuth, effects of centering the instrument and signal and effects of side lengths for accuracy of gyroazimuth measurement, the legal basis for such measurement in mining excavations and design quantities and location of gyroazimuth measurement in the underground network to obtain its better accuracy.

These theoretical arguments have been illustrated on the example of gyroazimuths measurement on the five sides of the existing underground network mainly focused on increasing its accuracy parameters by this additional measurement.
\end{abstract}

\section{PROJEKT, POMIAR I ANALIZA WPLYWU GIROAZYMUTÓW NA WYNIKI WYRÓWNANIA OSNOWY PODZIEMNEJ}

Słowa kluczowe: giroskop, pomiar azymutu, wyrównanie osnowy podziemnej

\begin{abstract}
Abstrakt
W artykule poruszono problematykę wpływu dodatkowo pomierzonych giroazymutów na dokładność osnowy podziemnej. Omówiono w nim takie zagadnienia jak: sposób pomiaru giroazimutu, poprawki wprowadzane do pomierzonych giroazymutów, wpływ ekscentrów stanowiska instrumentu i sygnału oraz długości boku na dokładność pomiaru giroazymutu, podstawy prawne takiego pomiaru w wyrobiskach górniczych oraz sposób projektowania ilości i miejsca pomiaru giroazymutu w sieci dołowej pozwalający uzyskać podwyższenie dokładności sieci dołowej. Podstawy teoretyczne zilustrowane zostały przykładem z pomiaru giroazymutów na pięciu bokach istniejącej sieci dołowej głównie pod kątem uzyskanego podwyższenia tym dodatkowym pomiarem jej parametrów dokładnościowych.
\end{abstract}

\section{INTRODUCTION}

A gyroscope is a stiff solid, the weight of which is distributed symmetrically towards its rotation axis, suspended in a manner enabling the change of position in space, and after introduction into rotational movement at a great angular speed, preserving the unchanged location of the rotational axis direction. A gyroscope with three levels of freedom is a gyroscope which provides a possibility for a rotation around three axes, while its main axis $(\mathrm{X})$ preserves the direction introduced upon start-up, which is an unchangeable direction towards the universe distribution (Scarborough 1958; Smith 1997). If a single degree of freedom of the gyroscope becomes limited, the devices 
adopts a quality applied in mining surveying, namely the ability to adjust its axis $(\mathrm{X})$ in accordance with direction of the point meridian, which is applied in the measurement of azimuths under the ground.

Measurements of azimuths are used for the mines orientation, as a result of which the coordinates of the mine control network, as well as the azimuths of all sides in the underground control network, are determined in a system of coordinates applicable on the surface (Velasco-Gómez et al. 2016). What is more, measurement of the azimuths under the ground is the only way to determine the side independently in long, suspended traverses and networks with adverse geometry. Inclusion of the measured azimuths, as additional observations, into the strict alignment of the underground network, improves its accuracy characteristics.

\section{A TOPOGRAPHIC AZIMUTH IN 2000 DISTRIBUTION}

An azimuth is a vertical angle included between the northern direction and a given side, measured in accordance with the direction of clock hands. The description presented above may be more specific about the "northern direction", as it can be determined by:

- The direction towards the polar star - when we deal with the astronomical azimuth or

- The direction pointed by a compass needle when we deal with the magnetic azimuth or

- A static direction towards the point meridian when we deal with a geographic azimuth or

- The direction determined by a vertical line of a topographic grid on a map prepared in a particular distribution of coordinates - when we deal with a topographic azimuth (in this system of coordinates).

It is possible to make conversions between the values of separate azimuths through application of the proper qualities presented in the literature (Department of the Army. U.S. 2004). The current system of coordinates is called " 2000 ". It is composed of four zones, which are Gauss-Krüger reflections of the GRS-80 ellipsoid in zones $3^{\circ}$, with central (axial) meridians: $15^{\circ}$, $18^{\circ}, 21^{\circ}, 24^{\circ}$ and the same scale on those meridians $m_{0}=0,999923$. In separate zones marked respectively: 2000/15, 2000/18, 2000/21, 2000/24, full (featured) coordinates are determined in division into zones $3^{\circ}$ :
- coordinate $X_{2000}$ is equal to an abscissa $x_{G K}$ of the Gauss-Krüger reflection:

$$
X_{2000}=m_{0} \cdot x_{G K}
$$

- a coordinate $Y_{2000}$ is determined with a formula (featured coordinates):

$$
Y_{2000}=c \cdot 1000000+m_{0} \cdot y_{G K}+500000[\mathrm{~m}],
$$

where $c$ is a single digit feature of the zone, specified respectively for the next zone as a natural number 5, 6 , 7 or 8 , with the following formula:

$$
c=L_{0}\left[{ }^{\circ}\right]: 3\left[^{\circ}\right] \text { (Feature-index of the zone), }
$$

where $L_{0}\left[{ }^{\circ}\right]$ - the surveying length (in degrees) of the central meridian of the zone (Osada 2014).

In the "2000" system, the topographic azimuth is defined as an angle, the left arm of which renders a straight line, perpendicular to the system's $x$ axis, and the right arm is a chord of a surveying line (Fig. 1).

The meridians convergence is a characteristic value calculated regardless of a particular reflection (e.g. Of the Gauss-Krüger reflection in the system 2000). The meridians convergence in reflection is an angle

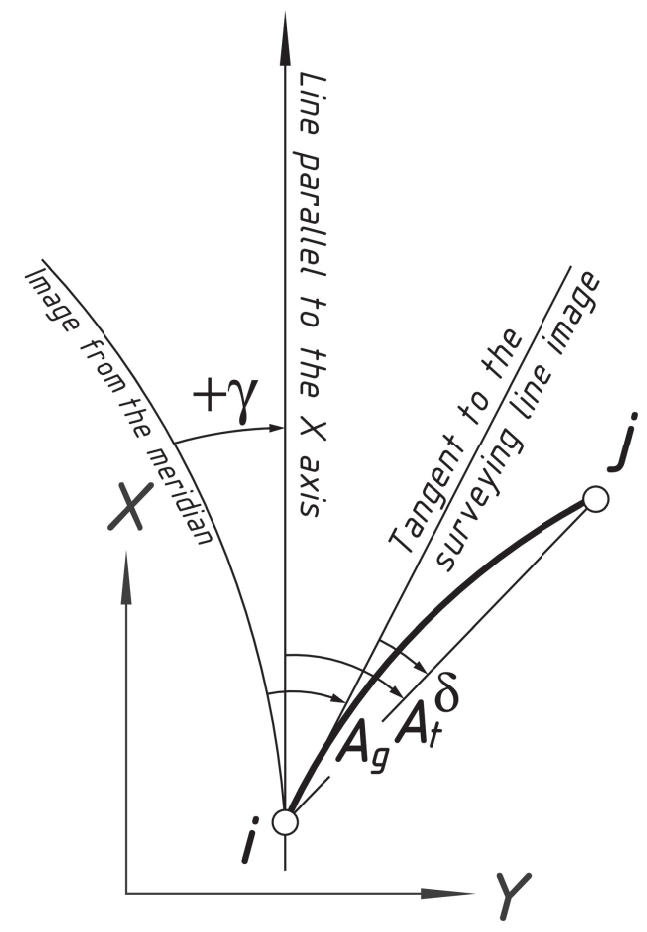

Fig. 1 Meridians convergence in the 2000 system Rys. 1 Zbieżność południków w układzie 2000 
between the tangents towards the meridian image at a given spot, and the straight line going through that point perpendicularly towards the $x$ axis (Fig. 1) (Soler and Fury 2000).

The convergence of the meridians $\gamma$ is always measured from the tangent towards the meridian image according to the clockwise direction. In all image points in the Gauss-Kruger reflections, located north from the equator image, and east from the image of a central meridian of a given zone, the meridian convergence is positive (Kahmen and Faig 1988).

The meridian convergence value in the Gauss-Kruger reflection in the system 2000 is determined in accordance with the following dependence (Gajderowicz 2009).

$$
\begin{aligned}
& \gamma^{c c}=\rho^{c c} \cdot\left(\frac{y}{N_{1}}\right) \cdot t_{1} \cdot\left\{1-\frac{1}{3} \cdot\left(\frac{y}{N_{1}}\right)^{2} .\right. \\
& \cdot\left(1+t_{1}^{2}-\eta_{1}^{2}-2 \eta_{1}^{4}\right)+\frac{1}{15} \cdot\left(\frac{y}{N_{1}}\right)^{4} \cdot \\
& \left.\cdot\left(2+5 t_{1}^{2}+3 t_{1}^{4}\right)\right\},
\end{aligned}
$$

where:

$N, t, \eta$ are functions of the ellipsoidal width $B$ and are described with the following formulas:

$$
N=\frac{1}{\sqrt{1-e^{2} \cdot \sin ^{2} \varphi}}
$$

$t=\tan \varphi$

$\eta=\mathrm{e}^{\prime} \cdot \cos \varphi$, where:

$\rho^{c c}$ - angular substitute,

$y-\mathrm{Y}$ coordinate of the observation place in the flat coordinates system 2000 ,

$a$ - large GRS-80 ellipsoid semi-axis,

$b$ - small GRS-80 ellipsoid semi-axis,

$e$ - the first eccentric of an ellipsoid, determined on the basis of the following dependence:

$$
e^{2}=\frac{a^{2}-b^{2}}{a^{2}}
$$

$e^{\prime}-$ the second eccentric of the ellipsoid, determined with the following formula:

$$
e^{\prime 2}=\frac{a^{2}-b^{2}}{b^{2}} \text {. }
$$

\section{MEASUREMENT OF THE AZIMUTH}

Measurement of the gyro azimuth applies instruments called gyro-theodolites, i.e. a theodolite or an electronic tachymetr, and a gyro-compass. A gyro-compass, enclosed in a housing, may be placed under a theodolite in a form of a so-called gyro-block, or placed on girders in a form of a so-called gyroscopic cap. As a result of the measurement carried out with a gyro-theodolite, we obtain a gyroscopic azimuth $A_{G}$, the value of which depends on the model of the gyro-theodolite applied for measurement. In order to obtain the value of the topographic azimuth $A_{T}$, there is a need to apply two corrections into the measured value of $A_{G}$ : a topographic correction $\Delta T$, and a correction regarding the difference in the meridians convergence at the spot of measurement and at the spot of the correction $\Delta T$, marked with $\Delta \gamma$.

Therefore, the formula for determination of the topographic azimuth value, on the basis of the gyro azimuth measurement adopts the following form:

$$
A_{T}=A_{G}+\Delta \mathrm{T}+\Delta \gamma
$$

\subsection{Topographic Correction}

The topographic correction $\Delta T$ is determined in the so-called base side located on the ground surface. The base side end points should be stabilized in a permanent manner, with a mark center prepared carefully, and their coordinates should be specified in the current system of coordinates (currently the 2000 system), with application of GPS technology in a static mode, in long measurement sessions, allowing determination of coordinates with the greatest precision possible. Value of the topographic base side is calculated on the basis of coordinates determined in such a manner. After determination of the base $A_{T_{0}}$ topographic azimuth, the gyro azimuth measurement is performed on the base side $A_{G_{0}}$.

The base side should be long enough, as during the gyro azimuth measurement on that side, the share of the centering error in the azimuth determination error was as small as possible.

According to the literature (Ogundare 2016), the angle of rotation $\varepsilon$ (the azimuth error) of the direction $k_{i-j}$ resulting from the linear errors of the instrument $e_{i}$ and the signal $e_{s}$ centering is specified in the eccentric measurements, as an adjustment for the direction, as determined in the following formula: 


$$
\varepsilon=\arcsin \frac{e_{i} \cdot \sin \alpha^{\prime}+e_{s} \cdot \sin \beta^{\prime}}{d_{i-j}}
$$

where:

$e_{i}-$ the linear value of the instrument centering error, $e_{s}-$ the linear value of the signal centering error,

$\alpha^{\prime}-$ a substitute of the eccentric directional angle of the position on the starting point of the base section $\beta^{\prime}$ - a substitute of the eccentric directional angle of the target on the end point of the base section $d_{i-j}-$ the base section length, illustrated on Fig. 2

In relation to the gyroscopic measurement, the value of the eccentrics may be treated as values of centering errors, this formula (3) may be adopted as a basis for calculations of the side base azimuth specification errors for the set sides lengths and assumes centering errors.

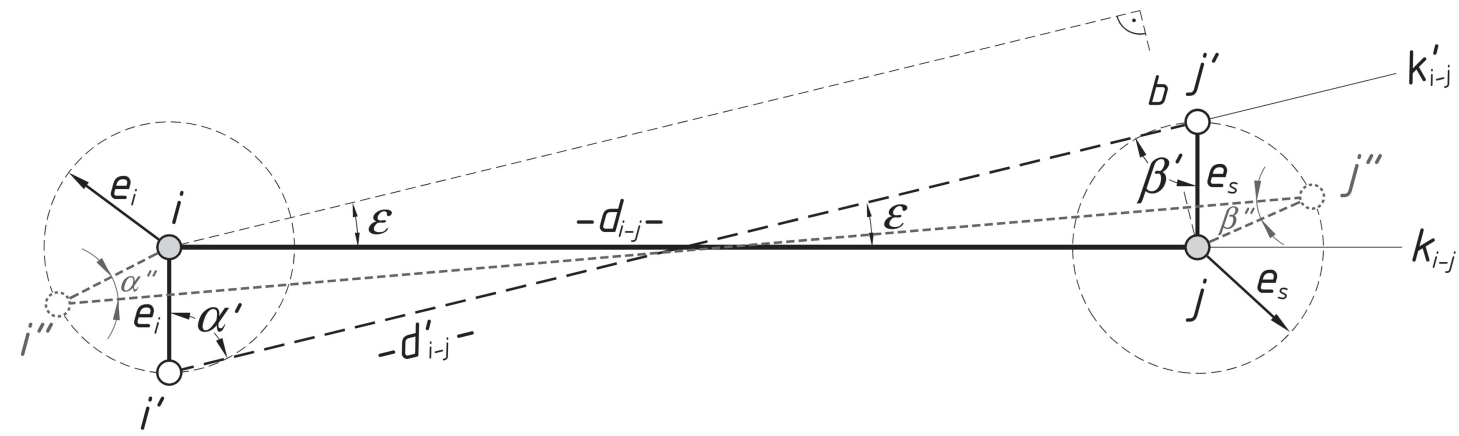

Fig. 2 Influence of the linear centering errors for the instrument $e_{i}$ and signal $e_{s}$ on value of correction for the measured direction Rys. 2 Wpływ liniowej wartości błędu centrowania instrumentu $e_{i}$ i sygnału $e_{s}$ na wartość poprawki do mierzonego kierunku

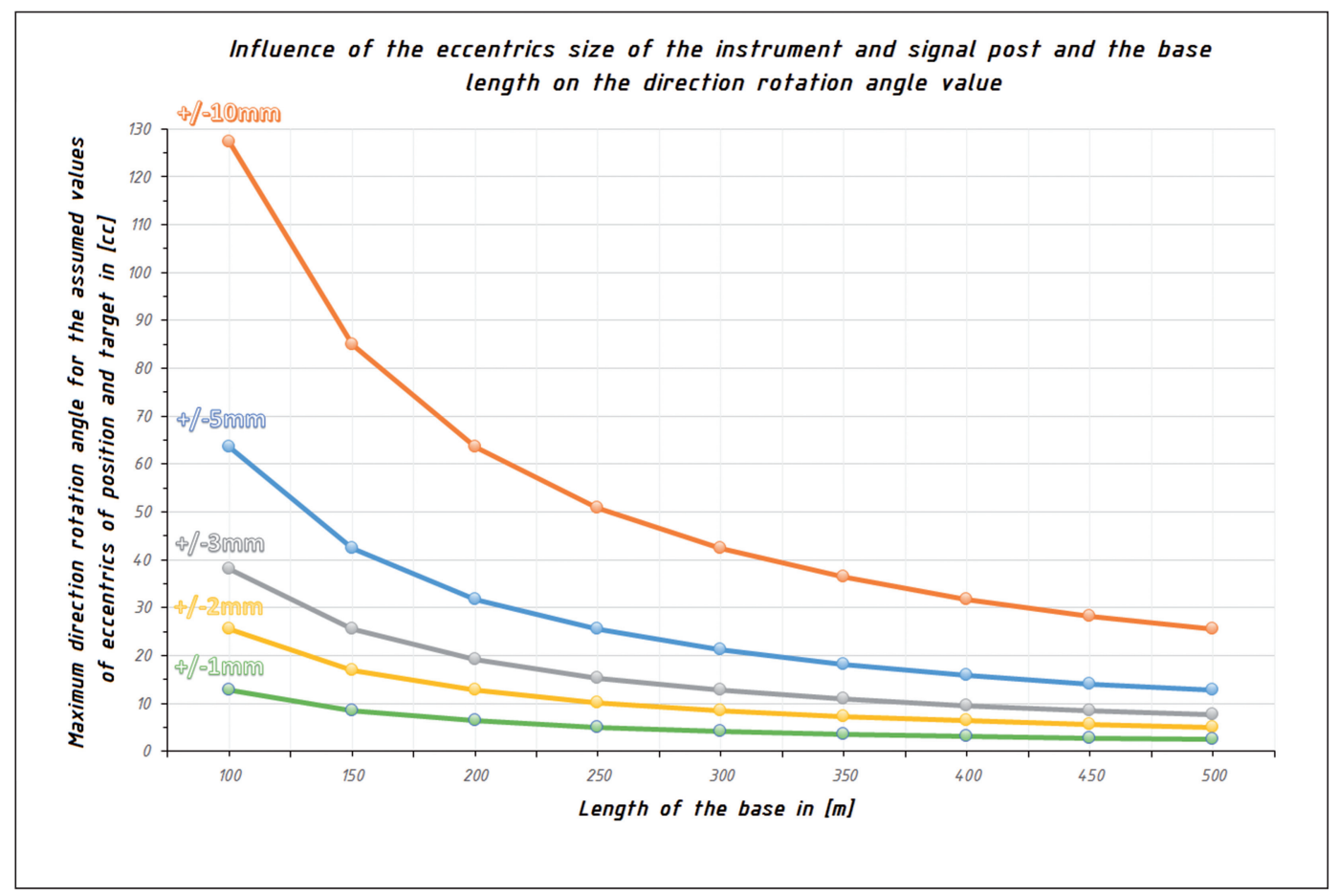

Fig. 3 Influence of the size of centering errors of the gyro-theodolite and the signal, as well as of the base side length on the azimuth error value

Rys. 3 Wpływ błędów centrowania giroteodolitu i sygnału, oraz wpływ długości bazy pomiarowej na wartość błędu średniego azumutu 
The diagram presented above (Fig. 3) demonstrates exemplary error values of the gyroscopic azimuth, measured on the base side, regarding the base side length, and results only from the gyro-theodolite and the signal centering errors. The same solution may be applied in assessment of the influence of the start and end point locations in the base side errors on the topographic azimuth value calculated from those coordinates.

Posts for the gyro-theodolite on points that pose the beginning and the end of the base should be stable, with no vibrations, protected from weather conditions (strong wind, changeable temperature, intensive insolation), which exert adverse influence on the measurement accuracy.

The gyro azimuth measurement on the base side should be carried out at least twice, both before and after the measurement of the side located under the ground, and its result $A_{G_{0}}$ should be averaged and compared with the calculated average error.

The end coordinates of the base side (current as of the day on which the measurement was taken with the gyro-theodolite) are used to calculate the topographic azimuth of the base $A_{T_{0}}$, and afterwards the topographic correction is calculated, regarding:

$$
\Delta T=A_{T_{0}}-A_{G_{0}}
$$

\subsection{Corrections Regarding the Difference in Meridian Convergence in the Measurement Spot and in the Determination Place of the Topographic Correction.}

The correction, regarding the meridians convergence differences in the measurement spot and in the determi- nation place of the topographic correction (marked with the $\Delta \gamma$ symbol) is often called in a shorter way, a meridian convergence correction. This correction is calculated as a convergence difference in the point that poses the center of the base side $\gamma_{\text {base }}$, and convergence in the point that poses the center of the chosen side of the mining control system $\gamma_{\text {side }}$, for which the azimuth is determined in accordance with the following formula:

$$
\Delta \gamma=\gamma_{\text {base }}-\gamma_{\text {side }},
$$

While the meridians convergence values are calculated in accordance with dependence (1), allowing strict determination of convergence, with an accuracy reaching up to 0.001 ".

The literature (Kowalczyk 1965; Milewski 1988; Pielok et al. 2011), presents a formula for determination of the correction value $\Delta \gamma$ according to the GaussKrüger system (scale on the axis meridian $m_{0}=1$ ), in the form:

$$
\Delta \gamma \cong 32,3^{\prime \prime} \cdot\left(Y_{\text {base }}-Y_{\text {side }}\right) \cdot \operatorname{tg} \varphi, \text { where: }
$$

$Y_{\text {base }}, Y_{\text {side }}$ - co-ordinates of the base side center and center of the side underground are expressed in [km]

$\varphi$ - latitude of the observational point.

However, according to the authors, this formula should not be applied in calculations of the topographic azimuth value within the 2000 system, because of too great a difference in relation to the value calculated in a manner dedicated to the 2000 system (according to the formula (1)). Calculation of the correction $\Delta \gamma$ with application of the formula (6) means that an error is made consciously, and related to the value presented in Table 1,

Table 1. Correction values $\Delta \gamma$ calculated for selected sides of the mine detailed control network and for the base side on the ground, with application of the strict formula for the system 2000 (1) and the pattern (6)

Tabela 1. Wartości poprawek $\Delta \gamma$ wyznaczone dla mierzonych boków kopalnianej osnowy szczegółowej i boku bazowego na powierzchni, z zastosowaniem wzoru ścisłego dedykowanego układowi 2000 (1) oraz wzoru (6)

\begin{tabular}{|c|c|c|c|}
\hline Mining control system side & $\boldsymbol{\Delta} \boldsymbol{\gamma}$ (Strict formula System 2000) [cc] & $\boldsymbol{\Delta} \boldsymbol{\gamma}$ (Pattern (6)) [cc] & Difference [cc] \\
\hline $3751-3752$ & -634 & -639 & 5 \\
\hline $4007-4008$ & -672 & -689 & 17 \\
\hline $4073-4084$ & -410 & -407 & 3 \\
\hline $4062-4063$ & -309 & -297 & 12 \\
\hline $3820-3821$ & -154 & -138 & 16 \\
\hline
\end{tabular}


in the "differences" column, what can be avoided in full thanks to the application of a formula dedicated to the 2000 system (applied by the authors). Value of the error (the "differences" column in Table 1) depends only on the erroneousness of the value $\Delta \gamma$ calculated in accordance to the formula (6), as the value $\Delta \gamma$ calculated according to a strict formula, regarding its accuracy (0.001") is error-free.

\section{LEGAL REQUIREMENTS REGARDING THE AZIMUTHS MEASUREMENT}

Legal requirements regarding the azimuths measurement under the ground are included in the Regulation of the Minister of Environment of $28^{\text {th }}$ October 2015, in Attachment 1, point "Detailed requirements regarding performance of surveying and geological works in order to prepare, update and complement the measurement-geological documentation".

According to those requirements, the gyro azimuth measurement should be carried out twice, regardless what should be understood as measurement performed from two ends of the side, and afterwards averaged. This results from the fact that the azimuth measured on two ends of the side is different. This difference arises from the fact that the direction of the gyro-compass axis is compliant with the meridian direction at the end point, and with the direction of the meridian at the side's end point. Regarding the non-parallelism of those directions regarding each other, in results of the gyro azimuth measurement from the start to the end point, and from the end to the start point (apart from the straight angle), the difference depends on:

The length of the side, location of the side towards the axis meridian of a given zone, as well as the mutual location of the end and the start points of the side. Therefore, the value that is most probable for the given side's azimuth is an average value calculated from two measurements carried out on two ends of the sides.

\section{THE AZIMUTHS MEASUREMENT DESIGN}

The average error of the side azimuth and average errors of the point location are the parameters that characterize accuracy of the underground control system (Regulation 2015). The average error of the side azimuth may be decreased through limitation of average errors for measurement of angle on all positions and/ or limitation of the average error for a chosen side (or sides) azimuth within the traverse. In order to estimate any potential effects of introduction of the gyroscopic measurement on the value of errors of the side azimuths in a given traverse of the detailed control network, we may use a simplified formula (Pielok et al. 2011):

$$
m_{A_{\text {kon }}}^{2}=m_{A_{\text {ost }}}^{2}+\sum_{i=1}^{n_{\text {ost }}} m_{\beta_{\text {ost }}},
$$

where:

$m_{A_{\text {kon }}}-$ the average azimuth errors of the last side in the traverse

$m_{A_{\text {ost }}}$ - the average error of the last gyro azimuth,

$n_{\text {ost }}$ - the number of angles in a given traverse.

Measurement of the azimuth on a given side of the control network, after introduction for alignment, will cause not only an obvious decrease in the azimuth error in this particular side (to the average error value of the measured azimuth), but also a decrease in the error values of azimuths on neighboring sides. Therefore, the measurements of gyro azimuths should be planned on the sides situated at a certain distance from each other, dependent on the number of occurring azimuth errors as well as the number of measured horizontal angles (the number of sides in the traverse), what should be considered through a proper initial analysis.

Through introducing value $m_{\beta}$ obtained from the current alignment of the network, into the formula (7), as the angle measurement error, and value $m_{A_{\text {ost }}}$ as the gyro azimuth determination error in underground conditions, performed with a given gyro-theodolite (e.g. for the Gyromat $2000 m_{A_{\text {ost }}}= \pm 23^{\mathrm{cc}}$ ) (Szafarczyk, Szafarczyk, and Pielok 2003; Eyre and Wetherelt 1995) we will obtain the expected errors of the azimuth of the analyzed side in the traverse. While comparing the obtained value with the previous value of the error (from current alignment of the network), we may estimate the profit and economic justification for performance of the gyroscopic measurement.

A similar analysis may be carried out for the average error of the point location, while calculating the coefficient $\eta$ specifying a percentage decrease in the point location error after introduction of an additional gyro azimuth (Pielok et al. 2011):

$$
\eta=\frac{m_{p_{k}}-m_{p_{(k+1)}}}{m_{p_{k}}} \cdot 100 \%,
$$


where:

$m_{p_{k}}-$ the average error of the end point location in the traverse, with $k$ measured gyro azimuths,

$m_{p_{(k+1)}}-$ the average error of the end point location in the traverse, with $k+1$ measured gyro azimuths,

If the obtained value $\eta$ remains at a level below $10 \%$, further introduction of gyro azimuths is unjustified.
6. INFLUENCE OF THE MEASURED

GYRO AZIMUTHS ON ACCURACY CHARACTERISTICS OF THE CHOSEN SITUATIONAL UNDERGROUND CONTROL NETWORK

In the selected mining facility, taking into account the accuracy characteristics of the existing mining con-

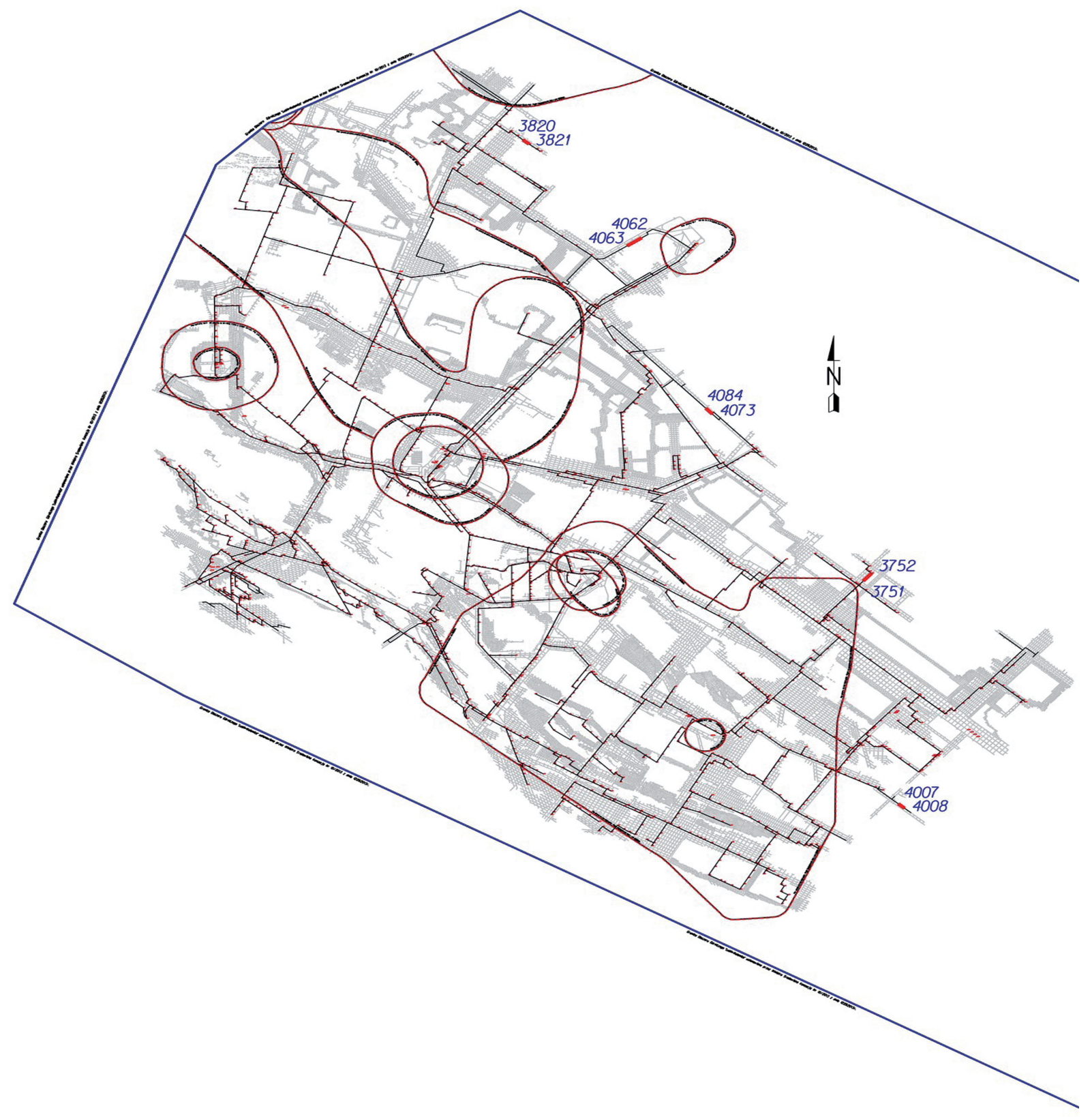

Fig. 4. The system scheme with location of the measured azimuths

Rys. 4. Schemat sieci wraz z lokalizacją pomierzonych giroazymutów. 
Table 2. A list of values of the sides azimuths and their errors before gyroscopic measurements

Tabela 2. Zestawienie wartości azymutów boków i ich błędów średnich przed wykonaniem pomiarów giroskopowych

\begin{tabular}{|c|c|c|c|}
\hline Side & $\begin{array}{c}\text { Topographic } \\
\text { azimuth }[\mathbf{g}]\end{array}$ & $\begin{array}{c}\text { Side length } \\
\text { of the mining control } \\
\text { network }[\mathbf{m}]\end{array}$ & $\begin{array}{c}\text { Average error of the azimuth } \boldsymbol{m}_{\boldsymbol{A}} \text { [cc] } \\
\text { from network alignment before gyro } \\
\text { introduction }\end{array}$ \\
\hline $3751-3752$ & 46.0084 & 151.988 & \pm 54 \\
\hline $4007-4008$ & 146.5564 & 98.586 & \pm 97 \\
\hline $4084-4073$ & 152.7658 & 115.615 & \pm 31 \\
\hline $4063-4062$ & 62.1281 & 91.664 & \pm 32 \\
\hline $3820-3821$ & 143.9848 & 94.488 & \pm 101 \\
\hline
\end{tabular}

trol network and potential possibilities for limiting the errors of the average azimuths of sides, and the average errors of points locations, it was planned to perform the gyroscopic measurements on the chosen five sides of the horizontal detailed control network, located in accordance with Fig. 4.

The localization of gyroscope measurements planned to be carried out, was dictated by the results of the analysis of present alignment of the underground network consisting of 1694 points stabilized on the depth of 700 to 1100 metres under the surface of the area. The alignment of the underground network was realized in Geonet programme.

Three sides, i.e.: 3751-3752, 4007-4008 and 3820 -3821 , were selected for measurement of the gyro azimuths regarding significant distance from the shafts (starting points of the suspended traverses), and the remaining two, i.e. Sides 4084-4073 and 4063-4062 were selected for gyro azimuth measurement regarding a highly adverse network geometry. The sides selected for gyroscopic measurements were characterized with error values for the azimuths, in the scope of $31 \mathrm{cc}$ to $101 \mathrm{cc}$, and the point location errors in the range of 5 to $13 \mathrm{~cm}$, what is presented in Table 2 and Table 3 for particular sides and points.

The measurements of the gyro azimuths were performed two times from each end of the selected side, obtaining eventually averaged values of the gyroscopic azimuths, which were calculated into the topographic azimuths through introduction of proper corrections discussed in chapter 3. Values of the topographic azimuths for selected sides are compared with errors in Table 4.
Table 3. A list of values of average errors of points location before gyroscopic measurements

Tabela 3. Zestawienie wartości błędów średnich punktów przed wykonaniem pomiarów giroskopowych

\begin{tabular}{|c|c|}
\hline Observation & $\begin{array}{c}\text { Average error of the point } \\
\text { location } m_{P}[\mathrm{~mm}]\end{array}$ \\
\hline 3751 & \pm 108 \\
\hline 4007 & \pm 145 \\
\hline 4084 & \pm 54 \\
\hline 4063 & \pm 45 \\
\hline 3820 & \pm 128 \\
\hline
\end{tabular}

The maximum azimuth difference from the two ends of the side was $91 \mathrm{cc}$ with a permissible value of $120 \mathrm{cc}$. As a result of measurement of gyro azimuths on those sides, and their introduction into the whole network alignment, the azimuths errors were limited on those sides by $54 \%$ on average, regarding the original error value (Table 4), and the average errors of those points location were limited by $9 \%$ on average, regarding the errors values before the gyroscopic measurements (Table 5).

The obtained values of the azimuths, together with erroneousness were compared with the azimuth values and their errors from before the performed gyroscopic measurements. As a result of the comparison it was found out that not all values are equal within the mean error boundaries, what may prove lack of stability of the points in the measurements performance area. 
Table 4. A list of topographic azimuths of the measured sides with errors

Tabela 4. Zestawienie wartości azymutów topograficznych mierzonych boków wraz z błędami

\begin{tabular}{|c|c|c|c|c|c|}
\hline \multirow[t]{2}{*}{ Side } & \multirow{2}{*}{$\begin{array}{c}\text { Topographic } \\
\text { azimuth (gyro } \\
\text { measurement) } \\
A_{T}[\mathrm{~g}]\end{array}$} & \multicolumn{2}{|c|}{$\begin{array}{l}\text { Azimuth difference between two } \\
\text { measurements from two endpoints } \\
\text { of the side }[\mathrm{cc}]\end{array}$} & \multirow{2}{*}{$\begin{array}{l}\text { Error of the azimuth } \\
m_{A}[\mathrm{cc}], \text { measured, } \\
\text { introduced for the } \\
\text { network alignment }\end{array}$} & \multirow{2}{*}{$\begin{array}{c}\text { Percentage } \\
\text { of the } \\
\text { original } \\
\text { error }\end{array}$} \\
\hline & & First measurement & Second measurement & & \\
\hline $3751-3752$ & 46.0164 & 35 & 27 & \pm 19 & 39 \\
\hline $4007-4008$ & 146.5536 & 55 & 91 & \pm 44 & 46 \\
\hline $4073-4084$ & 352.7644 & 10 & 12 & \pm 10 & 35 \\
\hline $4062-4063$ & 62.1259 & 78 & 68 & \pm 42 & 84 \\
\hline $3820-3821$ & 143.9847 & 41 & 6 & \pm 22 & 25 \\
\hline
\end{tabular}

Table 5. A list of average values of the points coordinates error after gyroscopic measurements.

Tabela 5. Zestawienie średnich wartości błędów położenia punków po wykonaniu pomiarów giroskopowych.

\begin{tabular}{|c|c|c|}
\hline Point & $\begin{array}{c}\text { Average error of the point } \\
\text { location } \boldsymbol{m}_{\boldsymbol{P}}[\mathbf{m m}] \\
\text { after introduction of gyro } \\
\text { into alignment }\end{array}$ & $\begin{array}{c}\text { Percentage of the } \\
\text { original error }\end{array}$ \\
\hline 3751 & \pm 89 & 82 \\
\hline 4007 & \pm 118 & 82 \\
\hline 4084 & \pm 54 & 100 \\
\hline 4063 & \pm 45 & 100 \\
\hline 3820 & \pm 119 & 93 \\
\hline
\end{tabular}

\section{SUMMARY}

Performance of the gyroscopic measurements and their implementation into the network alignment causes improvement of the accuracy characteristics of the network. It happens through a decrease of average error values for the azimuth after alignment, as well as a decrease of average error values of location of the point after alignment. The gyroscopic measurements carried out on selected sides of the underground control network caused limitation of the azimuth sides average errors by $62 \%$ on average, and the points location average errors, where the gyroscopic measurement was carried out, by $9 \%$ on average. Such a significant decrease of average errors may take place only if the sides, where the gyro azimuth measurement will be taken, are selected properly from the group of all sides that create the network, i.e.:

Their average azimuth error is of great value, which means that it is an error of values close to the permissible ones in the existing regulation (Regulation 2015), or the average error of point location has a high value, which results from adverse network geometry in the area of the planned measurement.

According to the authors, the theoretical analysis of the presented calculation formulas, as well as the collected experiences suggest that conditions necessary for performance of the gyroscopic measurements with the maximum possible accuracy and in accordance with the current technical knowledge is the application of the recommendations presented below in the measurement practice:

- a base side on the surface should have the greatest length possible, as it is reflected directly on the accuracy of the azimuth that is market on it, therefore also on the topographical correction value,

- the measurement of the gyroscopic azimuth needs to be carried out unconditionally from two ends of the measured side, as the most probable value for the given side azimuth is the average value from measurements obtained on two ends of the side,

- the measurement of the gyroscopic azimuth should not be performed on two neighboring sides, as it bears no economic justification, and it does not improve the accuracy parameters of the network after alignment. 


\section{ACKNOWLEDGMENTS}

Inclusion of the results from the gyro azimuth measurements presented in the articles, as well as the reports from the control network alignment in case of an exemplary underground mine, was permitted through a written consent expressed by the results administrator, which the authors would like to express their deep gratitude for.

The authors would like to extend their thanks to the GTC Wektor company, for its support in listing computational and graphical data, applied for analysis of influence of the measured gyro azimuths, on the accuracy characteristics of an exemplary network.

The article financed from statutory research 11.11.150.195

\section{BIBLIOGRAPHY}

Department of the Army. U.S. (2004). Army Map Reading and Land Navigation Handbook. Lyons Press.

Eyre, J.M., Wetherelt, A. (1995). "Taking azimuths underground." Mining Magazine; 172, no. 3, 163-166.

Gajderowicz, I. (2009). Odwzorowania kartograficzne. Podstawy. Wydawnictwo Uniwersytetu Warmińsko-Mazurskiego w Olsztynie, Olsztyn.

Kahmen, H., and Faig, W. (1988). Surveying. Walter de Gruyter, Berlin, New York.
Kowalczyk, Z. (1965). Miernictwo górnicze Orientacja kopalń. Wydawnictwo „Śląsk”, Katowice.

Milewski, M. (1988). Geodezja górnicza. Wydawnictwa AGH, Kraków.

Ogundare, J.O. (2016). Precision Surveying: The Principles and Geomatics Practice. Wiley\& Sons, New Yersey.

Osada, E. (2014). Geodezyjne uklady odniesienia. Geodetic reference systems. UxLan, Wrocław.

Pielok, J. et al. (2011). Geodezja górnicza. Wydawnictwa AGH, Kraków.

Regulation of the Minister of Environment on measurement-geological documentation from 28 October 2015 (item 1941), Official Journal 2015, together with Attachment 1: Detailed requirements regarding performance of surveying and geological works in order to prepare, update and complement the measurement-geological documentation

Scarborough, J.B. (1958). The gyroscope theory and applications. Interscience publishers, New York, London.

Smith, J.R. (1997). Introduction to Geodesy: The History and Concepts of Modern Geodesy. John Wiley \& Sons Inc., New York.

Soler, T., and Fury, R.J. (2000). "GPS alignment surveys and meridian convergence". Journal of Surveying Engineering, Vol. 126, No. 3, 69-82.

Szafarczyk, A., Szafarczyk, M., and Pielok, J. (2003). „Giromat 2000: szybki i dokładny pomiar azymutu”. Geodeta: magazyn geoinformacyjny, 1, 48-49.

Velasco-Gómez, J., Prieto, J. F., Molina, I., Herrero, T., Fábrega, J. and Pérez-Martín E. (2016). "Use of the gyrotheodolite in underground networks of long high-speed railway tunnels", Survey Review, in press. 